\title{
Does maternal serum progesterone level in early pregnancy predict placental dysfunction in third trimester?
}

\author{
Gülşen Doğan Durdağ (iD), Şafak Yılmaz Baran (iD, Songül Alemdaroğlu (iD), Hakan Kalaycı (iD, \\ Seda Yüksel Şimşek (D), Selçuk Yetkinel (iD), Serdinç Özdoğan (ID), Esra Bulgan Kılıçdağ (ID \\ Gynecology and Obstetrics Clinic, Başkent University Adana Hospital, Adana, Turkey
}

\begin{abstract}
Objective: Progesterone, which is necessary for maintenance of pregnancy, is secreted by corpus luteum until 10 weeks of gestation, and is produced from the placenta afterwards. Aim of this study is to investigate the relationship of serum progesterone concentrations measured in 6-8 weeks and 12 weeks of gestation with the parameters that may demonstrate placental dysfunction in the third trimester.

Methods: Relationship of the progesterone values measured at 6-8 weeks and 12 weeks of gestation with indicators of placental dysfunction, including hypertensive disorders of pregnancy, intrauterine growth restriction, preterm delivery and low birth weight, were evaluated. Furthermore, based on a previous study, two groups with progesterone levels below and above $11 \mathrm{ng} / \mathrm{mL}$ in early pregnancy were formed, and the difference between these groups regarding gestational outcomes were investigated.

Results: Progesterone concentrations at 6-8 and 12 weeks of gestation were not significantly different between the subgroups with and without gestational complications indicating placental dysfunction ( $p>0.05$ for all parameters). As for the two groups, significant difference was not found in terms of third trimester complications due to progesterone cut-off of $11 \mathrm{ng} / \mathrm{mL}$ at 6-8 weeks of gestation.

Conclusion: In this study, we did not find progesterone values measured at early and late first trimester periods to be associated with placental dysfunction in the third trimester. Also, we did not validate a previously suggested threshold value to predict gestational outcome. Therefore, routine first trimester progesterone screening in guiding pregnancy follow-up may not be appropriate.
\end{abstract}

Keywords: Hypertensive disorders, low birth weight, placental dysfunction, gestational complications, progesterone.

\section{Özet: Erken gebelik dönemindeki maternal serum progesteron seviyesi üçüncü trimesterdeki plasental disfonksiyonu öngörebilir mi?}

Amaç: Gebeliğin sürdürülmesi için gerekli olan progesteron, gebeliğin 10. haftasına kadar korpus luteum ve sonrasında plasenta tarafindan üretilir. Bu çalışmanın amacı, gebeliğin 6-8 ile 12. haftasında ölçülen serum progesteron konsantrasyonları ile üçüncü trimesterde plasental disfonksiyonu ortaya koyabilecek parametreler arasındaki ilişkiyi araştırmaktır.

Yöntem: Gebeliğin 6-8. haftaları ve 12. haftasında ölçülen progesteron değerleri ile gebelikte hipertansif bozukluklar, intrauterin gelişme geriliği, preterm doğum ve düşük doğum ağırlığı gibi plasental disfonksiyon belirtileri arasındaki ilişki değerlendirildi. Ayrıca, daha önceki bir çalışmaya dayanarak, erken gebelik döneminde 11 $\mathrm{ng} / \mathrm{mL}$ 'nin üzerindeki ve altındaki progesteron seviyelerine göre iki grup oluşturuldu ve gestasyonel sonuçlar yönünden bu gruplar arasindaki farklılık incelendi.

Bulgular: Gebeliğin 6-8. haftaları ve 12. haftasındaki progesteron konsantrasyonları, plasental disfonksiyona işaret eden gebelik komplikasyonlarına sahip olan ve olmayan alt gruplar arasında anlamlı şekilde farklı değildi (tüm parametreler için $\mathrm{p}>0.05$ ). Gebeliğin $6-8$. haftalarındaki $11 \mathrm{ng} / \mathrm{mL}$ 'lik progesteron eşik değeri nedeniyle üçüncü trimester komplikasyonları yönünden iki grup arasında anlamlı farklılik bulunmadi.

Sonuç: Bu çalışmada, birinci trimesterin erken ve geç dönemlerinde ölçülen progesteron değerlerinin üçüncü trimesterdeki plasental disfonksiyon ile ilişkili olmadığı sonucuna ulaştık. Ayrıca, gestasyonel sonucu öngörmek için daha önce önerilen eşik değeri valide etmedik. Bu nedenle, rutin birinci trimester progesteron taraması gebelik takibini yönlendirmede uygun olmayabilir.

Anahtar sözcükler: Hipertansif bozukluklar, düşük doğum ağırlığı, plasental disfonksiyon, gestasyonel komplikasyonlar, progesteron.

Correspondence: Gülşen Doğan Durdağ, MD. Gynecology and Obstetrics Clinic, Başkent University Adana Hospital, Adana, Turkey. e-mail: gulsendogan@hotmail.com / Received: December 7, 2020; Accepted: January 31, 2021

How to cite this article: Doğan Durdağ G, Yılmaz Baran Ş, Alemdaroğlu S, Kalaycı H, Yüksel Şimşek S, Yetkinel S, Özdoğan S, Bulgan Kılıçdă̆ E. Does maternal serum progesterone level in early pregnancy predict placental dysfunction in third trimester? Perinatal Journal 2021;29(1):39-45. doi:10.2399/prn.21.0291007 


\section{Introduction}

The importance of first trimester value of progesterone, which is necessary for preparation of the endometrium for implantation, support of decidualization required for a healthy maintenance of pregnancy, and development of immune tolerance against the fetus, has been shown in several studies on both single and multiple pregnancies. ${ }^{[1-3]}$ In some studies emphasizing the role of progesterone in predicting gestational prognosis in early pregnancy, maternal progesterone level below $35 \mathrm{nmol} / \mathrm{L}$ (11 ng/mL equivalent) has been found to be associated with vaginal bleeding and miscarriage. ${ }^{[4,5]}$ However, there are also studies stating different progesterone threshold values for healthy maintenance of pregnancy in the first trimester. ${ }^{[5,6]}$

Progesterone, which is secreted from corpus luteum until about 10 weeks of gestation, is produced from the placenta afterwards. ${ }^{[7]}$ Low progesterone level in the first trimester of pregnancy is associated with placental dysfunction. Relationship between first trimester progesterone concentrations and third-trimester gestational complications, such as hypertensive disorders, intrauterine growth restriction, oligohydramnios and preterm delivery, as well as low birth weight, were also investigated in few studies. ${ }^{[8-10]}$ In a recent study, low serum progesterone concentration during early pregnancy was found to be associated with an increase in hypertensive disorders of pregnancy in univariate analysis, but this relationship was not confirmed in multivariate analysis. ${ }^{[8]}$ This study also demonstrated that low progesterone level in the first trimester is associated with low birth weight ${ }^{[8]}$ However, the results of the few studies on this subject are not consistent. ${ }^{[9,1]}$ In addition, it has been reported that age and body mass index (BMI) in the first trimester also affect progesterone levels. ${ }^{[0]}$

The aim of this study is to investigate the relationship of progesterone values measured in 6-8 weeks and 12 weeks of gestation, as indicators of function of corpus luteum and placenta separately, with the parameters that may demonstrate placental dysfunction in the third trimester, including hypertensive disorders of pregnancy, intrauterine growth restriction, preterm delivery, and neonatal birth weight.

\section{Methods}

This study was carried out prospectively in the Gynecology and Obstetrics department of a tertiary center. Patients who had new diagnosis of a single intrauterine pregnancy of 6-8 weeks between April 2018 and April 2020, and who accepted to be included in the study were enrolled. Maternal serum progesterone concentrations at 6-8 and 12 weeks of gestation were measured by using a chemiluminescence microparticle immunoassay (ARCHITECT progesterone kit, Abbott, Donegal, Ireland). Routine followup of pregnancy was performed, and gestational complications including hypertensive disorders, intrauterine growth restriction and preterm delivery along with delivery week and birth weight parameters of the newborn were evaluated.

Patients with multiple pregnancies, patients who were treated with progesterone due to vaginal bleeding or threatened abortion, who had history of recurrent miscarriages, who achieved pregnancy by assisted reproductive techniques, who were smokers, and who had chronic hypertension or systemic diseases were excluded from the study.

All gestational outcomes were recorded. Patients' age, BMI calculated according to height and weight at first maternal visit, progesterone values measured at first visit (6-8 weeks) and at 12 weeks of gestation, gestational outcome as abortion or delivery, presence of hypertensive disorders (gestational hypertension / preeclampsia) occurring after the 20 weeks of gestation, presence of fetal intrauterine growth restriction, presence of preterm delivery, week of gestation at delivery and birth weight of the newborn were evaluated.

Spontaneous abortion was defined as loss of pregnancy without intervention before the 20 weeks of gestation, ${ }^{[12]}$ gestational hypertension was defined as blood pressure $\geq 160 / 100 \mathrm{mmHg}$ or $\geq 140 / 90 \mathrm{mmHg}$ in two separate measurements checked at least 4 hours apart after the 20 weeks of gestation, and preeclampsia was defined as gestational hypertension and proteinuria $(>300$ $\mathrm{mg}$ protein in 24-hour urine), or thrombocytopenia $(<100,000 \times 109 / \mathrm{L})$, renal failure (creatinine $>1.1 \mathrm{mg} / \mathrm{dL}$ ), and impaired liver tests in the absence of proteinuria. ${ }^{[13]}$ Preterm delivery was defined as delivery before 37 weeks of gestation, ${ }^{[14]}$ and low birth weight was defined as newborn weight less than 2500 grams. ${ }^{[15]}$ Intrauterine growth restriction was defined as estimated fetal weight less than 10th percentile for gestational age. ${ }^{[16]}$

The relationship of the progesterone values measured at 6-8 weeks and 12 week of gestation with hyper- 
tensive disorders of pregnancy, intrauterine growth restriction, preterm delivery and low birth weight were evaluated.

Furthermore, two groups with progesterone levels below and above $11 \mathrm{ng} / \mathrm{mL}$ in early pregnancy were formed, and the difference between these groups was investigated in terms of hypertensive disorders of pregnancy, development of intrauterine growth restriction, preterm labor and low birth weight.

In addition, progesterone values measured in both weeks of gestation were compared between patients aged $\leq 21$ and $>21$ years, as well as between patients with a $\mathrm{BMI}<30$ and $\geq 30 \mathrm{~kg} / \mathrm{m}^{2}$.

This study was approved by Institutional Review Board of Başkent University (Project no. KA18/105). Written informed consent was obtained from all patients.

Statistical analysis was performed by using the SPSS software (Version 25.0, SPSS Inc., Chicago, IL, USA).

Based on a previous study, under the assumption that pregnant women with early progesterone levels below $11 \mathrm{ng} / \mathrm{mL}$ have a high risk of low birth weight and that the low birth weight rate is 0.30 in pregnant women with progesterone levels above $11 \mathrm{ng} / \mathrm{mL},{ }^{[7]}$ to find doubling of this rate $(0.60)$ in pregnant women with low progesterone levels significant with $5 \%$ error and $80 \%$ power, the minimum sample size was determined as 41 patients per group.

Categorical measurements were presented by number and percentages, while continuous measurements were defined by mean and standard deviation or median and range (when data was not normally distributed). Mann-Whitney $U$ test for data, which was not normally distributed, was used for comparisons between groups. Chi-square or Fisher's exact tests were used to assess the categorical variables between groups. The value of $\mathrm{p}<0.05$ was accepted statistically significant for all tests.

\section{Results}

Of the 164 patients enrolled in the study, 2 patients were terminated during early pregnancy due to fetal anomaly, pregnancy of 8 patients resulted in spontaneous abortion, and the pregnancy follow-ups of the remaining 154 patients were continued in the third trimester (Fig. 1).

Of the 154 patients whose pregnancy was continued and resulted in delivery in the third trimester, 107

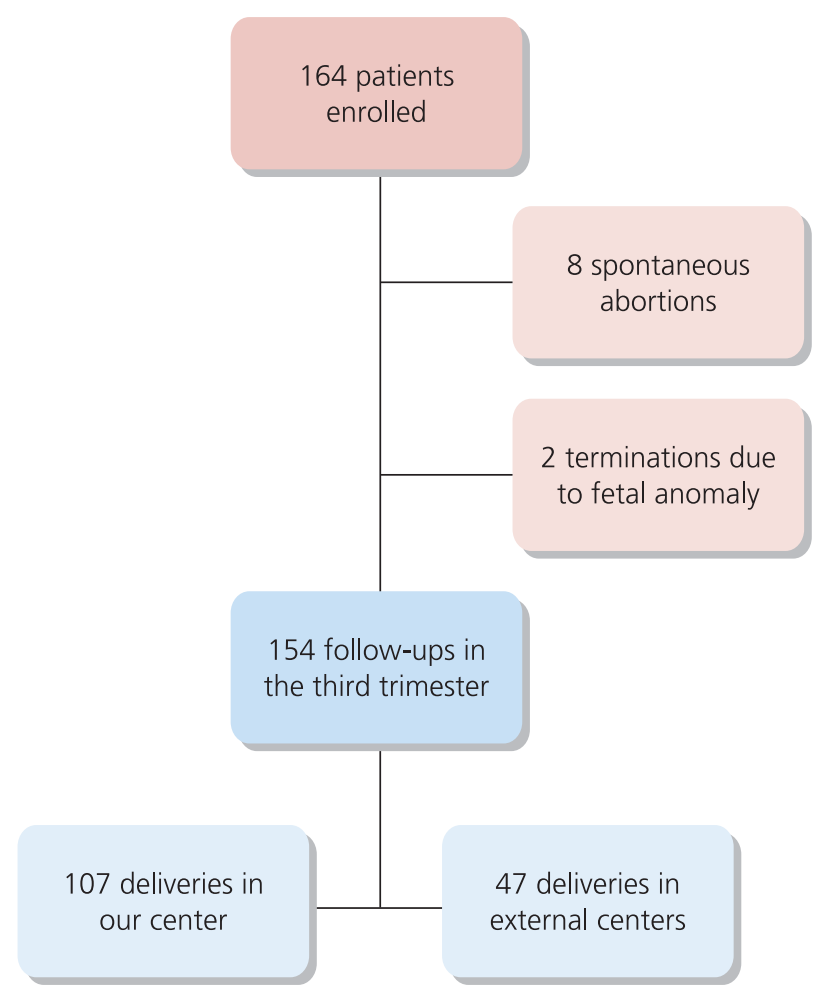

Fig. 1. Flowchart of the cohort.

patients gave birth in our center, while 47 patients were found to have given birth in an external center. Pregnancy and delivery information of the patients who gave birth in external centers was obtained by phone calls.

While progesterone values of all patients at 6-8 weeks of gestation were available, progesterone values at 12 week of gestation were obtained in 97 patients.

The mean age of the patients was $29.6 \pm 5.1$ years, and the mean BMI was $24.2 \pm 3.9 \mathrm{~kg} / \mathrm{m}^{2}$. Characteristics of the cohort are shown in Table $\mathbf{1}$.

Median progesterone value at 6-8 weeks of gestation was 8.90 (range $5.40-18.30$ ) $\mathrm{ng} / \mathrm{mL}$ in pregnancies resulting in abortion, while it was 16.5 (range 6.5-53.2) $\mathrm{ng} / \mathrm{mL}$ in the remaining of the cohort. Spontaneous abortion occurred before 12 weeks of gestation in 7 of 8 patients. Progesterone levels of the only patient, whose abortion occurred after 12 weeks of gestation, were 15.7 $\mathrm{ng} / \mathrm{mL}$ and $25.5 \mathrm{ng} / \mathrm{mL}$ at $6-8$ and 12 weeks of gestation, respectively.

When patients were evaluated in two groups according to progesterone levels at $6-8$ weeks of gestation below 
Table 1. Basal characteristics and third trimester outcomes.

\begin{tabular}{|c|c|}
\hline Basal characteristics & $\mathrm{n}=164$ \\
\hline Maternal age (year) (mean \pm SD) & $29.6 \pm 5.1$ \\
\hline BMI $\left(\mathrm{kg} / \mathrm{m}^{2}\right)($ mean $\pm \mathrm{SD})$ & $24.2 \pm 3.9$ \\
\hline Progesterone at 6-8 weeks of gestation $(\mathrm{ng} / \mathrm{mL}$ ) [median (min-max] & $16.1(5.4-53.2)$ \\
\hline Progesterone at 12 weeks of gestation $(\mathrm{ng} / \mathrm{mL})[$ median $(\min -\mathrm{max})](\mathrm{n}=97)$ & $25.4(12.3-48.8)$ \\
\hline Third-trimester outcomes & $n=154$ \\
\hline Delivery week (week/day) [median (min-max)] & $38 / 3(34 / 0-41 / 3)$ \\
\hline Birth weight of the newborn (g) [median (min-max)] & $3350(2050-4500)$ \\
\hline Preterm delivery [n (\%)] & $16(10.4)$ \\
\hline Low birth weight [n (\%)] & $11(7.1)$ \\
\hline Hypertensive disorders of pregnancy [n (\%)] & $10(6.5)$ \\
\hline Intrauterine growth restriction [n (\%)] & $19(12.3)$ \\
\hline
\end{tabular}

BMI: body mass index.

and above $11 \mathrm{ng} / \mathrm{mL}$, significant difference was not found between the two groups in terms of third-trimester complications including hypertension, intrauterine growth restriction, preterm delivery and low birth weight $(\mathrm{p}=1.000, \mathrm{p}=0.475, \mathrm{p}=1.000$, and $\mathrm{p}=1.000$ respectively $)$.

Among patients with and without low birth weight newborns, no difference was found regarding mean age, $\mathrm{BMI}$, and progesterone values at 6-8 weeks and 12 weeks of gestation ( $\mathrm{p}>0.05$ for all parameters).

Likewise, the mean age, BMI, and progesterone values of the patients at the $6-8$ weeks and 12 weeks of gestation with and without preterm delivery, with and without hypertensive disorders, and with and without intrauterine growth restriction were not significantly different ( $>0.05$ for all parameters). The relationship of progesterone values at $6-8$ weeks and 12 weeks of gestation with third-trimester gestational complications is shown in Table 2.

There were 6 patients at and under 21 years of age in the cohort. It was observed that progesterone values measured in both weeks did not change significantly between those at and under the age of 21 and above the age of 21 ( $\mathrm{p}=0.483$ for $6-8$ weeks of gestation, and $\mathrm{p}=0.104$ for 12 weeks of gestation) (Table 3 ).

There were 12 patients with $\mathrm{BMI} \geq 30$, and these patients had a lower progesterone value than the

Table 2. Early and late first-trimester progesterone values in absence and presence of pregnancy complications in the third trimester.

\begin{tabular}{|c|c|c|c|}
\hline & Low birth weight (-) & Low birth weight (+) & p-value \\
\hline Progesterone at 6-8 weeks of gestation [Median (min-max)] & $16.1(6.5-53.2)$ & $17.0(8.3-34.3)$ & 0.548 \\
\hline \multirow[t]{2}{*}{ Progesterone at 12 weeks of gestation [Median (min-max)] } & $25.4(12.3-45.6)$ & $21.6(20.9-28.0)$ & 0.521 \\
\hline & Preterm delivery (-) & Preterm delivery (+) & p-value \\
\hline Progesterone at 6-8 weeks of gestation [Median (min-max)] & $16.3(6.5-53.2)$ & $15.7(10.0-34.3)$ & 0.796 \\
\hline \multirow[t]{2}{*}{ Progesterone at 12 weeks of gestation [Median (min-max)] } & $25.6(12.3-45.6)$ & $21.6(20.5-29.3)$ & 0.242 \\
\hline & Hypertension (-) & Hypertension (+) & p-value \\
\hline Progesterone at 6-8 weeks of gestation [Median (min-max)] & $16.1(6.5-53.2)$ & $15.5(10.1-26.0)$ & 0.935 \\
\hline \multirow[t]{2}{*}{ Progesterone at 12 weeks of gestation [Median (min-max)] } & $25.4(12.3-45.6)$ & $24.6(20.5-44.2)$ & 0.614 \\
\hline & IUGR (-) & IUGR (+) & p-value \\
\hline Progesterone at $6-8$ weeks of gestation [Median (min-max)] & $16.2(6.5-53.2)$ & $14.5(8.3-40.3)$ & 0.730 \\
\hline Progesterone at 12 weeks of gestation [Median (min-max)] & $25.6(12.3-45.6)$ & $21.6(16.9-36.6)$ & 0.158 \\
\hline
\end{tabular}

IUGR: intrauterine growth restriction. 
Table 3. Progesterone values according to age and BMI.

\begin{tabular}{|c|c|c|c|}
\hline & Age $\leq 21$ & Age $>21$ & p-value \\
\hline Progesterone at 6-8 weeks of gestation [Median (min-max)] & $18.9(9.8-40.3)$ & $16.1(5.4-53.2)$ & 0.483 \\
\hline Progesterone at 12 weeks of gestation [Median (min-max)] & $19.0(18.3-19.7)$ & $25.5(12.3-48.8)$ & 0.104 \\
\hline & $\mathrm{BMI}<30$ & $\mathrm{BMI} \geq 30$ & p-value \\
\hline Progesterone at 6-8 weeks of gestation [Median (min-max)] & $16.5(5.4-53.2)$ & $11.4(6.8-29.8)$ & 0.006 \\
\hline Progesterone at 12 weeks of gestation [Median (min-max)] & $25.5(12.3-48.8)$ & $21.6(16.5-36.9)$ & 0.268 \\
\hline
\end{tabular}

BMI: body mass index.

patients with $\mathrm{BMI}<30$. The difference was significant for the progesterone values at 6-8 weeks of gestation $(\mathrm{p}=0.006)$, while statistical significance was not found for the progesterone values at 12 weeks of gestation $(\mathrm{p}=0.268)($ Table 3$)$.

\section{Discussion}

There are few studies, in which the relationship of firsttrimester serum progesterone concentrations with thirdtrimester placental function is investigated. In this study, the effects of progesterone from corpus luteum and placenta in the third trimester were evaluated separately; however, the serum progesterone concentrations measured at 6-8 weeks and 12 weeks of gestation were not found to be related to the complications associated with placental dysfunction in the third trimester.

Progesterone has been used as a parameter indicating the viability of pregnancy in the first trimester for many years, and different cut-off values have been proposed in several studies for this purpose. Daily et al. reported the mean progesterone values in viable and non-viable pregnancies in the first 8 weeks of gestation $22.1 \mathrm{ng} / \mathrm{mL}$ and $10.1 \mathrm{ng} / \mathrm{mL}$, respectively. ${ }^{[17]} \mathrm{Al}-$ Sebai et al. reported that a cut-off level of $45 \mathrm{nmol} / \mathrm{L}(14.13 \mathrm{ng} / \mathrm{mL})$ can determine viable and non-viable pregnancies with $87.6 \%$ sensitivity and $87.5 \%$ specificity. ${ }^{[18]}$ Elson et al. suggested that the progesterone cut-off level for normal viable pregnancy in the early weeks is $>25 \mathrm{ng} / \mathrm{mL}$. ${ }^{[19]}$ Abdelazim et al. reported that the $20 \mathrm{ng} / \mathrm{mL}$ cut-off value was $95.1 \%$ sensitive and $98.9 \%$ specific in diagnosing a nonviable pregnancy. ${ }^{[1]}$ A progesterone level $\leq 16 \mathrm{ng} / \mathrm{mL}$ $(50.7 \mathrm{nmol} / \mathrm{L})$ according to Duan et al., ${ }^{[20]}$ and a progesterone level $\leq 12 \mathrm{ng} / \mathrm{mL}(38.3 \mathrm{nmol} / \mathrm{L})$ according to Arck et al. was associated with an increased risk of abortion. ${ }^{[6]}$ $\mathrm{Ku}$ et al. suggested a cut-off level of $35 \mathrm{nmol} / \mathrm{L}$ (11 $\mathrm{ng} / \mathrm{mL}$ ) for spontaneous abortion in patients presenting with vaginal bleeding. ${ }^{[4,5]}$ However, the study was carried out on pregnant women who applied for vaginal bleeding, which may indicate that a population that was already unhealthy was selected.

Progesterone is one of the important mechanisms determining trophoblastic structuring in the first trimester. It has been suggested that low serum progesterone level in early pregnancy negatively affects trophoblastic invasion and impairs placentation. ${ }^{[8,21]}$ Besides, it has been reported that complications such as hypertensive disorders and preterm delivery are more common in the further weeks of gestation in patients with firsttrimester complications such as vaginal bleeding. ${ }^{[8,22]}$ On the other hand, it is known that progesterone, which originates from the corpus luteum at the beginning of the first trimester, is largely produced by the placenta after 10 weeks of gestation. ${ }^{[2,9]}$ However, the evaluated progesterone levels were measured in the early period of pregnancy in all studies, which reflects the function of the corpus luteum rather than the placenta.

In a retrospective study, $\mathrm{He}$ et al. investigated the relationship of progesterone in early pregnancy with third-trimester gestational complications and low birth weight, and the threshold value was accepted $11 \mathrm{ng} / \mathrm{mL}$ $(35 \mathrm{nmol} / \mathrm{L})$, based on a prior study, evaluating firsttrimester pregnancy viability, conducted in the same clinic. In this study, He reported that a progesterone level of $<11 \mathrm{ng} / \mathrm{mL}$ between 5 and 12 weeks of gestation was associated with low birth weight in advanced weeks, while there was no significant difference in other parameters showing placental dysfunction. ${ }^{[8]}$

In our study, we examined progesterone values in two separate weeks considering that progesterone originates mainly from the feto-maternal unit at the end of the first trimester and reflects the function of the placenta much more in this period, and therefore, progesterone 
measurement at 12 weeks of gestation may be more appropriate in predicting placental dysfunction in the following weeks. However, in our study, unlike the previous study, we found that the progesterone values measured neither at 6-8 weeks nor at 12 weeks of gestation were associated with complications related with placental dysfunction including low birth weight.

In a recent study, Shen et al. investigated the relationship between progesterone concentration in early pregnancy and risk of preterm delivery in a large population. However, unlike our study, progesterone level was mostly measured in risky patients, who had vaginal bleeding, instead of all population, and the majority of the tests were performed before 9 weeks of gestation, and most of the patients were treated with progesterone in this study. While the outcomes might be affected by inclusion criteria and progesterone treatment, similar to our results, low levels of progesterone were not found to be associated with risk of preterm birth. ${ }^{[10]}$

Besides, progesterone level can be affected by different parameters. It has been shown that the first-trimester maternal $\mathrm{BMI}$ is inversely proportional to the serum progesterone level. Obesity (BMI $\left.\geq 30 \mathrm{~kg} / \mathrm{m}^{2}\right)$, has been associated with lower progesterone levels $(<35$ $\mathrm{nmol} / \mathrm{L}){ }^{[9,23]}$ Maternal age between $18-21$ years has also been found to be associated with low progesterone. ${ }^{[9]}$ Our results are partly consistent with these findings, and progesterone level was significantly lower in the patients with high BMI at early weeks of gestation; however, low values at 12 th week measurements were not found to be significant. Progesterone values did not differ significantly in patients aged 18-21 years when compared to patients above 21 years old. However, low number of patients in these subgroups may have affected the results.

The most important limitation of the study is that, pregnancy of some of the patients with low progesterone levels resulted in miscarriage in the first trimester, and the failure of these patients to reach the advanced weeks of gestation led to a lack of data of an important group for whom gestational complications could be evaluated. The lack of data for 12th week-progesterone values of some patients whose progesterone levels were measured at 6-8 weeks of gestation is also a limitation of the study. On the other hand, prospective design, measurement of all progesterone values in the same laboratory, and completion of data on pregnancy complications, albeit by phone calls, are the strengths of the study.

\section{Conclusion}

Both of the progesterone values measured at the beginning and end of the first trimester were not associated with placental dysfunction in the third trimester. Also, we did not validate the previously suggested threshold value to predict gestational outcome. Therefore, routine first-trimester progesterone screening in guiding pregnancy follow-up does not seem to be logical. However, these results can be re-evaluated in further studies with larger populations.

Funding: This work did not receive any specific grant from funding agencies in the public, commercial, or not-for-profit sectors.

Compliance with Ethical Standards: The authors stated that the standards regarding research and publication ethics, the Personal Data Protection Law and the copyright regulations applicable to intellectual and artistic works are complied with and there is no conflict of interest.

\section{References}

1. Abdelazim IA, Belal MM, Makhlouf HH. Relation between single serum progesterone assay and viability of the first trimester pregnancy. J Turk Ger Gynecol Assoc 2013;14:6817. [PubMed] [CrossRef]

2. Goktolga U, Gungor S, Ceyhan ST, Keskin U, Fidan U, Gezginç K, et al. Assessment of the predictive value of serum progesterone levels on early pregnancy prognosis in spontaneous twin gestations: a prospective study. Eur J Obstet Gynecol Reprod Biol 2008;137:185-8. [PubMed] [CrossRef]

3. Arck P, Hansen PJ, Mulac Jericevic B, Piccinni M-P, SzekeresBartho J. Progesterone during pregnancy: endocrine-immune cross talk in mammalian species and the role of stress. Am J Reprod Immunol 2007;58:268-79. [PubMed] [CrossRef]

4. Lek SM, Ku CW, Allen Jr JC, Malhotra R, Tan NS, Østbye $\mathrm{T}$, et al. Validation of serum progesterone $<35 \mathrm{nmol} / \mathrm{L}$ as a predictor of miscarriage among women with threatened miscarriage. BMC Pregnancy Childbirth 2017;17:78. [PubMed] [CrossRef]

5. Ku CW, Allen Jr JC, Malhotra R, Chong HC, Tan NS, Østbye $\mathrm{T}$, et al. How can we better predict the risk of spontaneous miscarriage among women experiencing threatened miscarriage? Gynecol Endocrinol 2015;31:647-51. [PubMed] [CrossRef]

6. Arck PC, Rücke M, Rose M, Szekeres-Bartho J, Douglas AJ, Pritsch M, et al. Early risk factors for miscarriage: a prospective cohort study in pregnant women. Reprod Biomed Online 2008;17:101-13. [PubMed] [CrossRef]

7. Daya S. Luteal support: progestogens for pregnancy protection. Maturitas 2009;65 Suppl 1:S29-S34. [PubMed] [CrossRef]

8. He S, Allen JC, Malhotra R, Østbye T, Tan TC. Association of maternal serum progesterone in early pregnancy with low birth 
weight and other adverse pregnancy outcomes. J Matern Fetal Neonatal Med 2016;29:1999-2004. [PubMed] [CrossRef]

9. Hartwig IR, Pincus MK, Diemert A, Hecher K, Arck PC. Sexspecific effect of first-trimester maternal progesterone on birthweight. Hum Reprod 2013;28:77-86. [PubMed] [CrossRef]

10. Shen SY, Chen QZ, Zhang LF, He JR, Lu JH, Li WD, et al. Association between serum progesterone concentration in early pregnancy and duration of pregnancy: a cohort study. J Matern Fetal Neonatal Med 2020;33:2096-102. [PubMed] [CrossRef]

11. Troisi R, Hoover R, Thadhani R, Hsieh CC, Sluss P, BallardBarbash R, et al. Maternal, prenatal and perinatal characteristics and first trimester maternal serum hormone concentrations. Br J Cancer 2008;99:1161-4. [PubMed] [CrossRef]

12. Griebel CP, Halvorsen J, Golemon TB, Day AA. Management of spontaneous abortion. Am Fam Physician 2005;72:1243-50. [PubMed]

13. ACOG Practice Bulletin, Number 222: gestational hypertension and preeclampsia. Obstet Gynecol 2020;135:e237-e60. [PubMed] [CrossRef]

14. American College of Obstetricians and Gynecologists' Committee on Practice Bulletins-Obstetrics. Practice Bulletin No. 171: Management of preterm labor. Obstet Gynecol 2016;128:e155-64. [PubMed] [CrossRef]

15. Hughes MM, Black RE, Katz J. 2500-g low birth weight cutoff: history and implications for future research and policy. Matern Child Health J 2017;21:283-9. [PubMed] [CrossRef]

16. American College of Obstetricians and Gynecologists' Committee on Practice Bulletins-Obstetrics and the Society for Maternal-Fetal Medicin. ACOG Practice Bulletin No. 204: fetal growth restriction. Obstet Gynecol 2019;133:e97e109. [PubMed] [CrossRef]
17. Daily CA, Laurent SL, Nunley Jr WC. The prognostic value of serum progesterone and quantitative beta-human chorionic gonadotropin in early human pregnancy. Am J Obstet Gynecol 1994;171:380-4. [PubMed] [CrossRef]

18. Al-Sebai MAH, Kingsland CR, Diver M, Hipkin L, McFadyen IR. The role of a single progesterone measurement in the diagnosis of early pregnancy failure and the prognosis of fetal viability. Br J Obstet Gynaecol 1995;102: 364-9. [PubMed] [CrossRef]

19. Elson J, Salim R, Tailor A, Banerjee S, Zosmer N, Jurkovic D. Prediction of early pregnancy viability in the absence of an ultrasonically detectable embryo. Ultrasound Obstet Gynecol 2003;21:57-61. [PubMed] [CrossRef]

20. Duan L, Yan D, Zeng W, Yang X, Wei Q. Predictive power progesterone combined with beta human chorionic gonadotropin measurements in the outcome of threatened miscarriage. Arch Gynecol Obstet 2011;283:431-5. [PubMed] [CrossRef]

21. Miko E, Halasz M, Jericevic-Mulac B, Wicherek L, Arck P, Arató G, et al. Progesterone-induced blocking factor (PIBF) and trophoblast invasiveness. J Reprod Immunol 2011;90:50 7. [PubMed] [CrossRef]

22. Lykke JA, Dideriksen KL, Lidegaard Ø, Langhoff-Roos J. First-trimester vaginal bleeding and complications later in pregnancy. Obstet Gynecol 2010;115:935-44. [PubMed] [CrossRef]

23. Goh JY, He S, Allen JC, Malhotra R, Tan TC. Maternal obesity is associated with a low serum progesterone level in early pregnancy. Horm Mol Biol Clin Investig 2016;27:97-100. [PubMed] [CrossRef]

This work is licensed under the Creative Commons Attribution-NonCommercial-NoDerivs 4.0 Unported (CC BY-NC-ND4.0) License. To view a copy of this license, visit http://creativecommons.org/licenses/by-nc-nd/4.0/ or send a letter to Creative Commons, PO Box 1866, Mountain View, CA 94042 , USA.

Publisher's Note: The content of this publication does not necessarily reflect the views or policies of the publisher, nor does any mention of trade names, commercial products, or organizations imply endorsement by the publisher. Scientific and legal responsibilities of published manuscript belong to their author(s). The publisher remains neutral with regard to jurisdictional claims in published maps and institutional affiliations. 